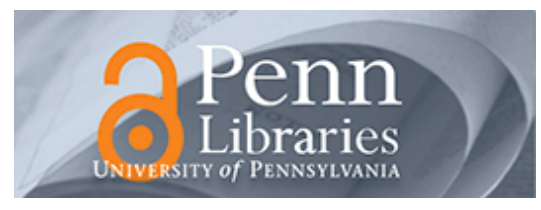

University of Pennsylvania

ScholarlyCommons

$11-2014$

\title{
The Discontent Cartel Member and Cartel Collapse: The Case of the German Cement Cartel
}

Joseph E. Harrington Jr

University of Pennsylvania

Kai Hüschelrath

Ulrich Laitenberger

Florian Smuda

Follow this and additional works at: https://repository.upenn.edu/bepp_papers

Part of the Business Commons, Economics Commons, and the Public Affairs, Public Policy and Public Administration Commons

\section{Recommended Citation}

Harrington, J. E., Hüschelrath, K., Laitenberger, U., \& Smuda, F. (2014). The Discontent Cartel Member and Cartel Collapse: The Case of the German Cement Cartel. International Journal of Industrial Organization, 42 106-119. http://dx.doi.org/10.1016/j.ijindorg.2015.07.005

This paper is posted at ScholarlyCommons. https://repository.upenn.edu/bepp_papers/81

For more information, please contact repository@pobox.upenn.edu. 


\title{
The Discontent Cartel Member and Cartel Collapse: The Case of the German Cement Cartel
}

\author{
Abstract \\ how it led to the collapse of the cartel.

\section{Keywords} \\ Collusion; Cartel; Antitrust enforcement; Cement

\section{Disciplines} \\ Business | Economics | Public Affairs, Public Policy and Public Administration
}

We hypothesize a particular source of cartel instability and explore its relevance to understanding cartel dynamics. The cartel instability is rooted in the observation that, upon cartel formation, the relative positions of firms are often fixed which may lead some growth-conscious members to be discontent. This incongruity between a cartel member's allocated market share and its desired market share may result in systematic deviations and the eventual collapse of the cartel. This hypothesis is then taken to the German cement cartel of 1991-2002. We argue that Readymix was such a discontent cartel member and, using a rich pricing data set, are able to characterize how Readymix deviated, how other firms responded, and 


\title{
THE DISCONTENT CARTEL MEMBER AND CARTEL COLLAPSE: THE CASE OF THE GERMAN CEMENT CARTEL
}

\author{
Joseph E. Harrington, Jr. ", Kai Hüschelrath*, \\ Ulrich Laitenberger, ${ }^{\circ}$ and Florian Smuda*
}

November 2014

\begin{abstract}
We hypothesize a particular source of cartel instability and explore its relevance to understanding cartel dynamics. The cartel instability is rooted in the observation that, upon cartel formation, the relative positions of firms are often fixed which may lead some growth-conscious members to be discontent. This incongruity between a cartel member's allocated market share and its desired market share may result in systematic deviations and the eventual collapse of the cartel. This hypothesis is then taken to the German cement cartel of 1991-2002. We argue that Readymix was such a discontent cartel member and, using a rich pricing data set, are able to characterize how Readymix deviated, how other firms responded, and how it led to the collapse of the cartel.
\end{abstract}

Keywords: Collusion, cartel, antitrust enforcement, cement

JEL Class L41, K21

\# Patrick T. Harker Professor, Department of Business Economics \& Public Policy, The Wharton School, University of Pennsylvania. Address: 3620 Locust Walk, Philadelphia, PA 19102. E-mail: harrij@wharton.upenn.edu. The project was financially supported by Strengthening Efficiency and Competitiveness in the European Knowledge Economies (SEEK) of the State Government of Baden-Württemberg, Germany as Grant \#SEEK-WuR-180031.

- ZEW Centre for European Economic Research, Competition and Regulation Research Group and MaCCI Mannheim Centre for Competition and Innovation. Address: P.O. Box 1034 43, D-68034 Mannheim, Germany, E-mail: hueschelrath@zew.de; University of Mannheim, L7, 3-5, 68131 Mannheim, Germany. We are grateful to Cartel Damage Claims (CDC), Brussels for providing us with the data set. We would also like to thank Bastian Sattelberger and Cung Truong Hoang for excellent research assistance. Hüschelrath was involved in a study on cartel damage estimations which was financially supported by CDC. The study is published in German (Hüschelrath, K., N. Leheyda, K. Müller, T. Veith (2012), Schadensermittlung und Schadensersatz bei HardcoreKartellen: Ökonomische Methoden und rechtlicher Rahmen, Baden-Baden). The present paper is the result of a separate research project.

- ZEW Centre for European Economic Research, Competition and Regulation Research Group and MaCCI Mannheim Centre for Competition and Innovation. Address: P.O. Box 1034 43, D-68034 Mannheim, Germany, E-mail: laitenberger@zew.de.

* ZEW Centre for European Economic Research, Competition and Regulation Research Group and MaCCI Mannheim Centre for Competition and Innovation. Address: P.O. Box 1034 43, D-68034 Mannheim, Germany, E-mail: smuda@zew.de. 


\section{Introduction}

How serious is the cartel problem depends, among other things, on how long cartels last. It is now well-established that cartels can manage to overcome inherent stability problems and operate successfully for years or even decades (see, e.g., studies on cartel duration reviewed in Levenstein and Suslow, 2006). Critical to understanding cartel duration is investigating why cartels collapse. In a recent study of 81 international cartels in the U.S. and the E.U., Levenstein and Suslow (2011) document a number of sources of collapse including an investigation by a competition authority, growth in non-cartel supply, and cheating by a cartel member.

Of particular interest is when a cartel's demise is associated with one of its members deviating from the collusive arrangement. Though not a property of theoretical models of collusion, such cheating is commonly observed and is well-documented, for example, in cartels in the markets for sugar (Genesove and Mullin, 2001) and bromine (Levenstein, 1996, 1997). Of course, cheating does not always produce collapse; indeed, as documented for the sugar cartel, firms may go to considerable lengths to avoid a breakdown of collusion. However, in other cases, such as in the bromine cartel, it is clear that a firm is intent on departing the cartel even if it means the cartel's demise.

The objective of this study is to better understand why and how a firm, which has willingly become a party to a cartel, would subsequently choose to cheat. Drawing from a collection of cartel cases, we identify certain features to how firms collude which, when interacted with certain firm traits, may result in a cartel having the seeds of its own destruction. This hypothesis is then taken to the German cement cartel of 1991-2002 which had a member that systematically cheated and whose behavior eventually caused the collapse of the cartel. Our analysis draws on both qualitative evidence from the judicial proceedings and quantitative evidence using a rich price data set.

In Section 2, a source of cartel instability is hypothesized based on a collection of European Commission cases. Section 3 describes the German cement industry and the recent cartel in that industry. Section 4 provides narrative evidence complemented with some factual evidence to argue that the cheating and collapse in the German cement market is consistent with the hypothesis expressed in Section 2. Section 5 provides additional supportive evidence by empirically investigating pricing behavior surrounding the deviation and during the post-cartel environment. Section 6 concludes. 


\section{The Discontent Firm and Cartel Collapse}

Drawing on a collection of past cartels, this section describes a set of ingredients that can be a source of instability for intermediate goods cartels. We then show, in Section 4, how this analysis can shed light on the collapse of the German cement cartel.

In forming a cartel, there is generally a consensus among firms that prices should be raised. Though there may be some disagreement as to the extent of the price increases (with higher cost firms preferring higher increases), the far more prevalent source of disagreement lies in the market allocation: How is demand to be distributed among the firms participating in the cartel? Resolving that contentious issue has been far from easy for many cartels. For example, the lysine cartel had no difficulty agreeing to a common price but struggled with finding sales quotas to satisfy all members. ${ }^{1}$ Though initially able to raise price without having settled upon a market allocation, the arrangement soon unraveled with a series of price cuts as firms reduced prices to either claim more market share or in response to a reduction in its market share. Only after coming back to the bargaining table and settling on an allocation did successful collusion ensue.

While there is no one formula by which this market allocation dilemma is solved, the most commonly documented method is to use the historical allocation. In the case of sales quotas, each firm is allocated a market share equal to its historical market share. The organic peroxides cartel used sales from 1969-70 to set collusive quotas for $1971 .^{2}$ In the cartels in the vitamins A and E markets in the early 1990s, market shares were set at 1988 levels and firms agreed to maintain these shares in response to market growth. For the folic acid cartel, cartel member Roche negotiated with the Japanese cartel members as a group and ultimately settled on market shares based on 1990 sales which gave Roche a share equal to $42 \%$. The Japanese producers then allocated their $58 \%$ share amongst themselves according to their 1990 market shares. The citric acid and zinc phosphate cartels used the average of firms' sales over the previous three years. The sorbates cartel set the allocation for 1978 between Hoechst and the four Japanese producers based on sales volumes in 1977 for each region of the world, and the Japanese producers allocated their aggregate share according to 1973-77 sales.

As exemplified by these cases, cartel formation often implies freezing the relative positions of firms in that collusive market shares are set equal to the competitive market shares at that time. If a firm interested in growing its sales is then to comply with the collusive arrangement, sales growth

1 Official Journal of the European Union, L 152/24, 7.6.2001, Case COMP/36.545/F3 - Amino Acids, Decision of June 7, 2000.

2 The cartels described in this section are from Harrington (2006) which draws on European Commission decisions. 
must come from overall increases in market demand or, in the case of a non-all-inclusive cartel, taking sales away from non-cartel members. While the higher profits of collusion is surely a powerful reason to participate in a cartel, many managers are implicitly or explicitly rewarded through increases in sales or market share. Indeed, in the non-collusive environment preceding cartel formation, it is not atypical for a firm to have a clearly articulated goal of growing market share. ${ }^{3}$ Regardless of the circumstances, a firm desiring to grow its sales or market share typically has that goal thwarted when it joins a cartel.

For this reason, cartel formation may create a tension for some firms between earning higher profits and improving their performance as measured by sales growth and a rise in market share. A firm might join the cartel with every intent to abide by the allocation for the sake of higher prices, as long as market demand growth is sufficient to produce firm sales growth. Or a firm might be disingenuous and join the cartel with the intent of trying to sell more than its allocation. In either case, though cartel stability requires that the desire to grow sales be moderated and to grow market share be suppressed, some firms may not be content to abide.

As examples, the lysine and choline chloride cartels suffered from a cartel member striving to grow market share. At the root of their discontentment with the collusive allocation was a recent expansion in capacity. The lysine cartel was composed of all five global producers and, as the fourth largest supplier, Sewon was initially allocated a sales quota of 33,500 tons in 1992 which meant a market share of $13.4 \%$. In spite of having received an increase in its allocation to 37,000 tons for 1994 and a proposed expansion to 39,000 tons for 1995, Sewon was not satisfied. It expressed that "its priorities for 1995 were 50,000 tons and 20\% market share." ${ }^{4}$ At a meeting with cartel leader Ajinomoto in November 1994, "Sewon indicated that a new plant was being built for the Chinese market and that it intended to increase its capacity to 50,000 tons by 1995-96 [so] the 39,000 tons proposed [quota] was not acceptable considering its level of investment." 5 After failing to close the gap between the quota that Sewon wanted and what the other cartel members were willing to give, Sewon declared that "it could not cooperate with the other companies on production

3 Consider, for example, the Section 5 case before the U.S. Federal Trade Commission in which Valassis' CEO was accused of inviting its rival News America to collude during a July 2004 securities analysts call (In the Matter of Valassis Communications, Inc., File No. 051 0008, Docket No. C-4160, April 28, 2006). Among other announcements, it stated its plan to abandon its goal to grow market share to 50 percent.

4 Official Journal of the European Union, L 152/24, 7.6.2001, Case COMP/36.545/F3 - Amino Acids, Decision of June 7, 2000; paragraph 148.

5 Ibid, paragraph 149. 
quantities but it could cooperate on pricing. It was concluded that Sewon's future status could be that of an observer and not as a participant in the quota allocation scheme.”6

At the last meeting of all members of the choline chloride cartel, the European producers (BASF, UCB, and Akzo Nobel) sought to maintain their market shares in the Latin American and Asian markets. However, cartel member Chinook rejected that proposal and insisted on more market share. It is not coincidental that Chinook had recently opened a new production facility in Singapore. At the end of the meeting, Chinook conveyed that it would no longer participate in meetings of the cartel.

To summarize the preceding discussion, what has been documented is that: 1) cartels often fix the market allocation according to firms' market shares in the year (or recent years) prior to cartel formation; 2) some cartel members may prove discontent with not growing market share, especially when they have expanded capacity; and 3) this incongruity between a cartel member's allocated quota and its desired output can be a source of cartel instability. In Sections 4 and 5, this construct is used to understand the collapse of the German cement cartel in 2002. Prior to doing so, we first provide some background information on the market for cement in Germany and the German cement cartel.

\section{The German Cement Industry and Cartel}

\subsection{The German Cement Industry}

Cement can broadly be defined as a substance that sets and hardens independently, and can bind other materials together. Cement used in construction is largely so-called hydraulic cement that hardens when the anhydrous cement powder is mixed with water. Although cement is usually seen as a homogenous product, the current European standard EN 197-1 for common cement defines no less than 27 different cement types. However, a large fraction of the cement sales in most European countries refers to the so-called CEM I cement which contains only Portland cement clinker and no other possible constituents.

The cement production process can be subdivided into three main steps: the preparation of the raw mixture, the production of the clinker, and the preparation of the cement. Cement producers tend to locate near the most important raw material source (which typically is lime). The production of the clinker through heating in a cement kiln is not only quite inflexible - in the sense that the costs per unit increase quickly with a reduction in capacity utilization - but is also particularly

6 Ibid, paragraph 143. 
energy-intensive (which is why cement producers have started to partly replace clinker by other constituents during the final step of the preparation of the cement). In general, production characteristics suggest that high start-up costs are incurred with entry into the cement market, e.g., due to the necessary access to lime resources or the installation of production plants and mills.

The most common use for cement is in the production of concrete. Concrete is widely used in the construction industry, either in the form of prefabricated units (such as panels, beams, and slabs), or "cast-in-place" concrete needed for the construction of building superstructures, roads, or dams. Cement demand then follows the seasonality of the construction business, with peaks in the summer months and reduced activity in the winter months.

In the sale of cement, transportation costs are a significant fraction of overall costs. Transportation by trucks is the most frequent mode though, when available, transportation by rail or sea is cheaper. In the absence of the latter options, this might suggest that the relevant geographical markets are rather local. Various decisions in cartel and merger cases (e.g., by the European Commission) state that cement can also be profitably delivered over longer distances when there is appropriate infrastructure. The Commission concluded in this respect that the "relevant market is therefore Europe, made up of an overlapping pattern of interdependent markets."

While cartel agreements are - as in our case - defined for rather small regions, they often have to deal with the possibility of cross-supplies at the border of those markets. Given such interdependence of local markets, cartel agreements are often intended to allocate the overall market or at least have to settle disputes between neighboring markets. As a consequence, a largely local pattern of deliveries cannot necessarily be attributed to economic constraints to long distance deliveries.

Figures 1 and 2 describe the patterns in production and capacity in the German cement market from 1991 to 2005. As shown in Figure 1, domestic cement consumption increased in the early 1990s - most likely in response to a construction boom after the reunification of Germany in 1990 - but decreased quite substantially starting in the late 1990s. At the same time, overall domestic production stayed rather constant with increased exports making up for the decline in domestic demand. Cement imports peaked in the mid-1990s and subsequently fell quite significantly. Overall, exports and imports are small relative to domestic production.

7 European Commission (1994), Commission imposes fines on a cement producers' cartel, Press release on 30 November 1994, available at http://europa.eu/rapid/pressReleasesAction.do?reference=IP/94/1108\&format= HTML\&aged=1\&language=EN\&guiLanguage $=$ en (last accessed on 18 July 2014). 


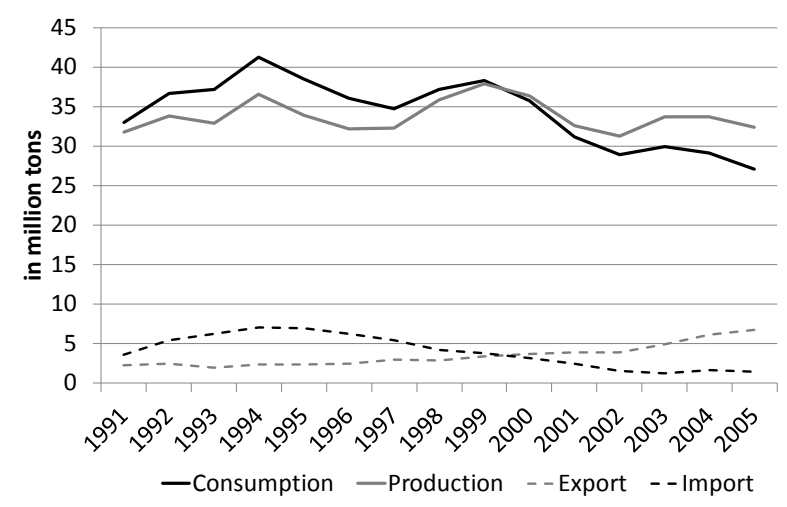

Figure 1: Production and Consumption in the German Cement Industry, 1991-2005 Data source: Verein Deutscher Zementwerke e.V.

Figure 2 describes what was happening in terms of the capacity of German cement manufacturers. The number of plants was reduced quite substantially over time which led to a corresponding reduction in overall oven capacity. Although many closures were of small production plants, the substantial reduction in capacity alongside the relatively constant production volumes in Figure 1 suggest that overall capacity utilization rose, though it is important to keep in mind capacity utilization could have declined in some parts of Germany. While small plants were being shuttered, at the same time most large cement companies were either modernizing existing plants or replaced several old plants with the construction of a new larger plant.

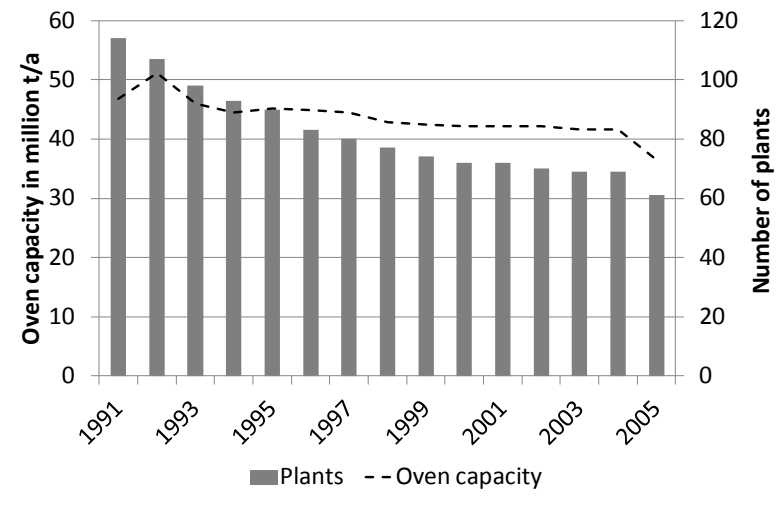

Figure 2: Capacity in the German Cement Industry, 1991-2005

Data source: Verein Deutscher Zementwerke e.V. 


\subsection{The German Cement Cartel}

Cartel formation in cement markets is a common occurrence with documented cartels in many countries around the world including Poland ${ }^{8}$, India ${ }^{9}$, South Africa ${ }^{10}$, and Argentina ${ }^{11}$. The frequency of cartelization is explained by several factors that make collusion profitable and collusive agreements stable. First, due to transportation costs and economies of scale, cement markets are typically highly concentrated. Second, cement is a homogeneous product which makes competition especially intense (and collusion particularly attractive) and coordination on a common price fairly easy. Third, while firm demand is highly elastic because of the lack of product differentiation, market demand is highly inelastic as the demand for cement is derived from final products for which cement makes up a small percentage of cost. Finally, entry costs are high so collusion is unlikely to induce new entrants though there is always the threat of imports from more distant cement manufacturers. For all of these reasons, numerous cement cartels have been discovered throughout the world.

At least since 1991, a cement cartel existed in Germany among the six largest cement companies - Dyckerhoff AG, HeidelbergCement AG, Lafarge Zement GmbH, Readymix AG, Schwenk Zement KG, and Holcim (Deutschland) AG. ${ }^{12}$ For 2005, these six cement producers controlled 86.1\% of capacity in Germany with the market share distribution being as follows: Heidelberg: 26.1\%, Dyckerhoff: 16.0\%, Schwenk: 13.9\%, Cemex (formerly Readymix): 12.9\%, Holcim: 10.3\%, and Lafarge: 6.9\% (Harder, 2006). The cartel ended in February 2002, the circumstances of which will be described later. At the time of its demise, one of the cartel members approached the German competition authority for amnesty which then initiated a legal case against the cartel members.

The six large cement companies divided up the German cement market by constructing four regional cartels: north, south, east, and west. Given plants located in different parts of the country,

8 Office of Competition and Consumer Protection (2009), Cement Cartel Smashed, available at: http://www.uokik.gov.pl/news.php?news_id=1768 (last accessed on 30 September 2014).

9 Competition Commission of India (2012), Builders Association of India - through Shri O. P. Dua \& Shri Rahui Goel - Informant, available at http://www.cci.gov.in/May2011/OrderOfCommission/292011.pdf (last accessed on 30 September 2014).

10 Competition Commission of South Africa (2010), Annual Report 2009/2010, available at: http://www.compcom.co.za/assets/Publications/Annual-Reports/Annual-Report-2009-10-Final.pdf (last accessed on 30 September 2014).

11 Comisión Nacional de Defensa de la Competencia (2005), Decision No. 513, available at: http://www.mecon.gov.ar/cndc (last accessed on 30 September 2014).

12 The latest cement cartel was not the first infringement of anti-cartel laws by cement companies in Germany. For example, in 1989, the German Federal Cartel Office fined a market-sharing cement cartel in southern Germany; see Higher Regional Court, 2009, paragraphs 49 and 190ff. 
some firms were in multiple regional cartels. For example, Dyckerhoff was present in all four regional cartels, while Readymix was in the east and west cartels. Collusion was implemented through market-sharing agreements that set sales quotas for members of each regional cartel. (Details on the agreements will be provided in Section 4.1.) This allocation was monitored by having each cartel member report its production on a regular basis to the industry trade association, the Federation of the German Cement Industry (Bundesverband der Deutschen Zementindustrie or BDZ). Those numbers were used to monitor for compliance with the market-sharing agreement. In addition, the cartel gradually tried to incorporate and/or acquire small and medium sized firms from outside the cartel. This behavior was particularly relevant in dealing with lower-priced imports of cement from Eastern Europe. ${ }^{13}$

While the cartel operated successfully for many years, a first indication of possible instability was the announcement in November 2001 by one of the larger cartel members, Readymix, that it would start replacing cement deliveries by other cartel members to its subsidiary concrete producers downstream. The implementation of this announcement in February 2002 effectively meant an increase in Readymix's cartel quota and thus would have been interpreted by the other cartel members as a deviation from the agreement. In late 2003, HeidelbergCement revealed plans to acquire Readymix; however, the German Federal Cartel Office successfully prevented these plans due to various competition concerns. ${ }^{14}$ It was then announced in September 2004 that Cemex, a Mexican company which was not previously active in the German market, was planning to acquire Readymix, which it did in March 2005.

\section{Readymix as a Discontent Member of the Cement Cartel}

Consistent with the cartels described in Section 2, we will argue that a similar situation arose in the German cement cartel by providing evidence that: 1) the German cement cartel established quotas based on historical market shares; 2) a cartel member (Readymix) was discontent with its allocation associated with an expansion in capacity; and 3) the discontent member eventually engaged in an aggressive deviation that caused the cartel to collapse. In this section, we document the first two parts of this argument and then, in Section 5, examine pricing behavior to document and describe the manner in which the deviation occurred and how the response of the other firms effectively meant the end of the cartel.

13 For further information on the German cement cartel, see, e.g., Blum (2007), Friederiszick and Röller (2010) and Hüschelrath and Veith (2011, 2014).

14 See “Operation Skunk bremst Heidelcement,”Die Welt, 3 November 2003, available at http://www.welt.de/printwelt/article270432/Operation-Skunk-bremst-Heidelcement.html (last accessed on 22 July 2014). 


\subsection{Market-Sharing Agreements}

As already mentioned in Section 3.2, the German cement cartel consisted of four regional cartels with each having its own market allocation scheme. In the south region, a ten-year average of market shares from 1979-1989 was calculated such that Dyckerhoff initially received a market share of $11.3 \%$, Heidelberg of $40.6 \%$ and Schwenk $19.4 \% .{ }^{15}$ In the north region - which actually consisted of three agreements - Alsen (later Holcim) was allocated a market share of 65\%, Nordzement ${ }^{16}$ received an allocation of 20\%, and Dyckerhoff together with several small and medium-sized Westphalian enterprises had 15\% for the Bremen and Hamburg area. ${ }^{17}$ This allocation was again based on the actual market shares for the preceding decade. ${ }^{18}$ In the west region, quotas were based on the quotas of a planned structural crisis cartel. ${ }^{19}$ In the east region, the four largest cartelists - Lafarge, Dyckerhoff, Readymix, and Schwenk - agreed to sales quotas starting in 1991. As the east region cartel covered the former German Democratic Republic (GDR), these firms only started producing there after unification in 1990. As entry involved the purchase of stated-owned plants, the allocation was set according to the historical capacity shares of those plants at the time of the GDR. ${ }^{20}$ In sum, the German cement cartel had a market allocation scheme whereby a cartel member's sales quota was largely determined by its historical market share.

\subsection{Capacity Expansion by Readymix}

Readymix produced both cement and ready-mix concrete. While its cement plants were located in the areas encompassed by the east and west regional cartels, its concrete production took place all over Germany. Until the late 1990s, Readymix was the fourth largest German cement firm (in terms of production capacity) and then became the third largest firm with the acquisition of a large full cycle plant from Wülfrather Zement GmbH in the west region. ${ }^{21}$ With German unification in 1990, there was the anticipation of growing demand for cement in the east region which led Readymix to heavily invest in a plant in Rüdersdorf near Berlin starting in 1990. One report states that

\footnotetext{
Judgment of the Higher Regional Court (2009), p. 38.

Nordzement merged with Alsen in 1997.

7 Judgment of the Higher Regional Court (2009), p. 27.

18 The other two agreements in the north were a result of negotiations (with deliveries from neighboring regions being the main reason for dispute).

19 Judgment of the Higher Regional Court (2009), pp. 35f.

20 Judgment of the Higher Regional Court (2009), pp. 44f.

21 Furthermore, three grinding plants (Schwelgern and Sötenich in the West, Coswig in the East) and one integrated plant (Essen) were acquired. However, the Sötenich and Coswig grinding plants were transferred to Lafarge while the Essen plant was closed in 1999. Furthermore, Lafarge closed the Coswig grinding plant in 1999.
} 
Readymix invested about 600 million Euros in Rüdersdorf over 1990-2003. ${ }^{22}$ As we will now argue, this investment resulted in a significant expansion of Readymix’s capacity.

Over the time of the cartel, Readymix had nine cement plants of which five were integrated plants with ovens. Two of those plants were acquired in 1998 and two were sold in $1998 .{ }^{23}$ Data is available on oven capacity for three of Readymix’s plants. Readymix’s two plants in Beckum had maximal capacity of 1.255 mtpa (million tons per annum) in 1998, while the plant in Rüdersdorf had $1.4 \mathrm{mtpa}$ in 1993 which increased to $2.1 \mathrm{mtpa}$ by 1996 and to $2.4 \mathrm{mtpa}$ by 1999 . Turning to mill capacity, data is available for seven of Readymix’s plants. Putting aside the Rüdersdorf plant, the largest capacity was $1.0 \mathrm{mtpa}$ (which was for the Dortmund plant) and the aggregate capacity of the other six plants reached a maximum of $3.5 \mathrm{mtpa}$. By comparison, the Rüdersdorf plant's capacity ranged over 1.8 to 2.4 mtpa. Of these seven plants, the Rüdersdorf plant comprised 52\% of total mill capacity in 1993 and 59\% in 1994, and just under 50\% of mill capacity over the entire period of 1993-2002. A complete tallying of Readymix’s cement capacity is provided in the annual report of its parent company, UK-based RMC Group. As of 1999, Readymix had capacity in Germany of 6.0 mtpa which means that the Rüdersdorf plant comprised $40 \%$ of total capacity. ${ }^{24}$ Based on this evidence, it is clear that the addition of the Rüdersdorf plant was a substantial increase in Readymix’s capacity.

\subsection{Imperfectly Observed Deviations by Readymix}

While there were episodic deviations from the collusive allocation by various cartel members, the court documents support Readymix’s being, by far, the most egregious offender. In the west region, Readymix under-reported 500,000 tons from its plant in Westfalia to the trade association BDZ. ${ }^{25}$ However, the most serious deviation occurred in the east region, where, as noted above, Readymix had increased its production capacity substantially with the construction of its Rüdersdorf plant. In the 1993 to 1997 period, Readymix had concealed - according to a calculation by Dyckerhoff about 4.024 of 10.436 million tons of cement (about 39 percent) produced at its Rüdersdorf plant. ${ }^{26}$

22 See Tagesspiegel, 02.10.2003, available at: http://www.tagesspiegel.de/wirtschaft/zementkonzerne-wollenzusammen-mischen/453220.html (last accessed on 1 October 2014).

23 The following information stems from World Cement Directories (1991, 1996, 2002). We do not report the respective data for the plants in Sötenich and Coswig as they were transferred - four months after the acquisition of Wülfrather Zement - to Lafarge (see footnote 21 above).

24 RMC Group p.l.c., Annual Report and Accounts, 1999; p. 16.

25 Judgment of the Higher Regional Court (2009), p. 36. Recall that BDZ compiled sales data used in monitoring compliance.

26 According to Readymix, the excess amount was only about 2.9 million tons of cement. 
While it is not clear how extensive was the punishment that the other members of the east region cartel inflicted on Readymix upon discovery of this deviation, there is some evidence of Readymix providing compensation to Dyckerhoff and Schwenk. In the case of Schwenk, Readymix transferred an annual quota of 70,500 tons for 1999-2001. ${ }^{27}$ Furthermore, the court documents reveal that Readymix was harmed as a result: “After the discovery of the falsely reported quantities, Readymix 'choked back its anger,' as the reduction to the agreed quantities and the necessary compensation measures had negative consequences (especially the under-utilization of Rüdersdorf), but [Readymix] wanted to avoid a competitive confrontation.”28

\subsection{Perfectly Observed Deviations by Readymix}

To summarize up to this point, the German cement cartel set quotas based on historical market shares. Readymix invested in a significant capacity expansion in the east region with the Rüdersdorf plant. Reflecting a desire to increase capacity utilization in the Rüdersdorf plant, Readymix produced above its quota and falsely reported its sales to the industry trade association. In response to this deviation being detected and in order to avoid a return to competition, Readymix provided some compensation and apparently returned to respecting the sales quotas.

The situation faced by Readymix - low capacity utilization due to an increase in capacity without a commensurate rise in its sales quota - was then seriously exacerbated by the slump in demand in the east region. The primary source of demand for cement is the production of concrete for new construction. Figure 3 reports the construction activity of new buildings for both western Germany (which encompasses the areas covered by the cartels in the north, south, and west regions) and eastern Germany (which is the same area as encompassed by the cartel in the east region). While construction was steadily rising in the east region over 1993-97, it suffered a sharp decline starting in 1998 and that decline continued for the remaining time of the German cement cartel. For example, while about 65,000 new buildings were constructed in eastern Germany in 1997, that value had fallen almost by half to 34,000 in the year of the cartel's breakdown, 2002. This decline in demand was not expected as of the early 1990s when Readymix expanded its capacity: "[T]he need for reconstruction in East Germany ... made investment in the East Germany cement industry attractive. ... [I]n contrast to predictions, at the end of the 1990s, demand plummeted due to a dramatic drop in business in the building industry." ${ }^{29}$ The difficult situation this posed for

27 Judgment of the Higher Regional Court (2009), pp. 36 and 51.

28 Ibid, p. 66.

29 Blum (2007), p. 7. 
Readymix was expressed in the 1999 annual report of its parent company which stated that eastern Germany is "continuing to be characterised by over-capacity." 30

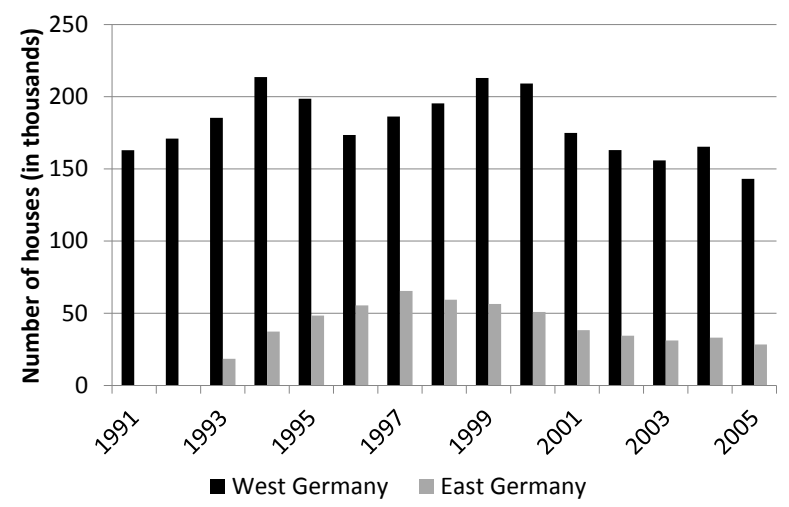

Figure 3: Construction of new buildings in West and East Germany, 1991-2005 Data source: Hauptverband der deutschen Bauindustrie e.V.

In response to the deteriorating situation, Readymix made a decisive change in its strategy. As argued above, it was already dissatisfied with its quotas, particularly in the east region where it had significantly expanded its capacity. This discontentment was evidenced by the over-production and under-reporting of sales to the BDZ. In November 2001, Readymix announced that it would start supplying cement to its downstream concrete producers in southern Germany. As this would mean displacing the cement supplied by the south regional cartel (which did not include Readymix), such an action would be an unambiguous deviation from the market allocation. In February 2002, Readymix went through with its announcement. While this action need not, by itself, imply the collapse of the cartel, we take this date as a candidate end to the cartel.

This change in the collusive allocation - whereby, effectively, Readymix acquired part of other firms' quotas in the south region - could be interpreted as a one-time event that need not imply further deviations. In that case, it would certainly be plausible that the other cartel members might have accommodated this action (perhaps with some compensation in the west and east regions in which Readymix was a cartel member) rather than pursue the less attractive alternative of dismantling the cartel with its return to competition. Indeed, if a firm thought this move by Readymix necessarily implied the end of the cartel then Readymix's announcement in November 2001 should have induced its rivals to immediately cut price, of which there is no evidence.

If in fact the other cartel members did not discontinue colluding in response to this announcement (for which we'll provide evidence later), Readymix had three options. First, it could

30 RMC Group p.l.c., Annual Report and Accounts, 1999; p. 15. 
limit its deviation to this acquisition of sales in the south region and otherwise abide by the agreedupon market allocation, with the hope that the cartel remained intact. Second, it could deviate by increasing the discounts it offered buyers, with the hope that it could pick up more sales while delaying the time at which it was discovered by the other firms. Repeating the type of deviation it had previously engaged in, along with the action take in the south region, would probably eventually lead to the departure of Readymix from the cartel and the likely collapse of the cartel. Third, it could choose a more aggressive but also more transparent deviation strategy by cutting list prices. Offering higher discounts is limited in terms of its impact because only those buyers who engage in negotiations with Readymix will learn that it is selling cement at lower prices. However, a lower list price is information made available to all buyers and could induce many of them to solicit a price quote from Readymix. The potential impact of this deviation on Readymix's demand is then much larger. However, a lower list price is not just observed by buyers, it is also widely and immediately observed by the other cartel members. Thus, the "lower list price" deviation strategy would likely bring both a bigger increase in firm demand and a faster and more aggressive response by rival firms than a "higher discount" deviation strategy. To examine which of the three options that Readymix pursued, we turn to analyzing list and net prices.

\section{Empirical Analysis of Prices}

In this section, we examine pricing patterns both during the time of the cartel and after Readymix started supplying cement to its subsidiaries in the south. The goals are to examine Readymix's pricing behavior and the pricing response of rival firms, and assess what this all meant for cartel stability. Following a description of the dataset and the corresponding descriptive statistics in Section 5.1, the econometric model and main results are provided in Section 5.2.

\subsection{Data Set and Descriptive Statistics}

The raw data was collected by Cartel Damage Claims (CDC) of Brussels and consists of approximately 500,000 market transactions from 36 customers (both large and small) supplied by the German cement cartel during January 1993 to December 2005. ${ }^{31}$ Market transactions include information on product types, dates of purchases, delivered quantities, cancellations, rebates, early

31 The data set used in this paper covers deliveries that account for about 4 percent of total sales in Germany. However, because the large cement producers are vertically integrated downstream (e.g., in the ready-mix concrete industry), the share of the data set from the non-integrated segment of the market is substantially larger than $4 \%$. Given that Hortaçsu and Syverson (2007) find little evidence that vertical foreclosure effects are quantitatively important in the U.S. cement and concrete industries, it is reasonable to assume that the observed prices in our dataset are similar to prices overall. 
payment discounts, and free-off charge deliveries as well as locations of the cement plants and unloading points. We have supplemented this raw data set with information on all cement plants located in Germany as well as those near the German border. Using Google Maps, all coordinates were retrieved for each unloading point in our sample and the number of independent cement suppliers located within a radius of 150 kilometers (road distance) of those coordinates serves as a measure of the set of available suppliers to a customer. Additionally, we calculated the road distance to the nearest Eastern European plant which measures import competition.

The empirical analysis focuses on one specific cement type called 'CEM I' (Standard Portland Cement) which accounts for almost 80 percent of all available transactions in the relevant time period. ${ }^{32}$ We only use transactions with cement plants of the six large cartel firms located in Germany (as they are comparable in their cost structures during the time of the data set). ${ }^{33}$ Furthermore, for reasons of consistency and interpretation, the transaction data is aggregated on a monthly basis at the level of the cement plant-cement seller-unloading point-cement consistency (32.5, 42.5 and $52.5 \mathrm{~N} / \mathrm{R})$. In the course of this aggregation process, prices and discounts were weighted by their respective quantities. Hence, one observation unit represents the monthly (quantity weighted and deflated) average list or net price per ton (excluding freight costs) of a specific consistency of CEM I cement for a specific plant-seller-unloading-point relation. The final dataset contains 25,930 observations encompassing 424 different plant-customer-unloading-point relations. ${ }^{34}$

List prices refer to the prices sent to actual or potential customers via price lists and modified by price increase letters which are sent at least annually. However, as we do not have a complete set of past price lists for all suppliers, we use the 'gross price' as stated on customer invoices as a measure of the list price. ${ }^{35}$

List prices are usually not the prices paid by the customers as different types of discounts are generally negotiated and contracted between the parties. In the German cement market, there are basically three types of discounts granted by the producers. First, immediate discounts are granted

32 The share of pure CEM I cement is decreasing towards the end of the data set as cement companies began to partially substitute raw cement ("clinker") with other materials such as sand or ash in order to reduce carbon dioxide emissions.

33 Firms (at least partially) controlled by the six largest cement companies were also included in the data set. An example is Anneliese Zementwerke AG for which HeidelbergCement and Dyckerhoff held the controlling majority share in the 1990s (with Heidelberg taking over full control in 2003). To better control for time constant factors, we also included plants of firms that were independent of the six largest suppliers in the cartel period but were acquired by one of the large players shortly afterwards (such as, e.g., Milke Zement GmbH \& Co. KG and Buderus Guss who are both now part of HeidelbergCement).

34 In sum, there are 36 customers with 197 unloading points served by 52 different plants.

35 In our data set, gross prices sometimes vary between customers, however, not to a significant extent. 
at the time when the transaction is made. The size of this type of rebate depends on the quantity bought as well as customer traits. The most extreme version of an immediate discount is delivery free of charge. ${ }^{36}$ Second, non-immediate discounts are granted if a customer shows its loyalty to a supplier, e.g., by surpassing a specific overall volume of cement within a specific period of time (typically one year). The customer then gets money back. This kind of discount refers to the overall quantity within a certain time period and does not depend on one single purchasing act. Finally, early payment discounts of 2 to 3 percent are granted if the invoices are settled early on. Given these types of discounts, the net prices were calculated by subtracting all these different types of discounts from the list prices. Non-immediate discounts were evenly distributed over the monthly quantities within the corresponding time period. ${ }^{37}$

The total discount is defined as the sum of the immediate discount (granted with the purchase) and the so-called end-of-month/year discounts (that were allocated proportionally to the respective monthly or yearly transactions). The immediate discount share equals the immediate discount divided by the sum of all discounts. In order to ease comparison, the invoiced freight costs were subtracted from both list and net prices. ${ }^{38}$

All prices were deflated to the year 2005 by a price index for industrial activities obtained from the German Statistical Office. As the industry price index reflects most cost changes of essential inputs (such as coal, fuel oil and electricity), we do not add cost shifters to the price regressions. Demand shifters are also omitted as aggregate cement demand is highly price inelastic. ${ }^{39}$ Table 1 provides the descriptive statistics of the data set. The "cartel period" is January 1993 to February 2002 and the “post-cartel period” runs from March 2002 to December 2005.

36 Deliveries free of charge are included in the dataset. For the calculation of average list prices, we omitted deliveries free of charge as they are customer-specific.

37 The distribution of retroactive discounts over the entire year has one drawback. If a supplier suddenly grants more non-immediate discounts, the resulting net prices do not adjust in the same year over time, i.e., net prices prior to the event are too low while afterwards they are too high. However, as the granting process typically happens at the end of the year (and we do not observe the underlying supply contracts), we believe this bias is small.

38 According to Friederiszick and Röller (2002), some suppliers use FOB pricing, uniform delivered price and base point pricing for setting their list prices. Consistent with what we observe in our dataset, Friederiszick and Röller (2002) find that those pricing schemes do not play a big role as cement firms regularly grant discounts. These discounts reflect that, in fact, price discrimination seems to be the more relevant practice in the German cement industry. Given that we do not observe the entire German market and also exclude some (smaller) firms in the dataset, we refrain from modelling spatial competition. As higher transport costs (on average) should lead to higher cement prices (on average), we subtract transport costs, even if both list and net prices without freight cost may vary with distance. Unfortunately, the exact pricing scheme itself cannot be determined with our data.

39 For example, Miller and Osborne (2014) report an aggregate elasticity of -0.02 for the median year for the US cement industry which is "consistent with the conventional wisdom that materials such as steel, asphalt, and lumber are poor substitutes for portland cement in most construction projects.” (p. 232) 
Table 1: Descriptive Statistics

\begin{tabular}{lcccccc}
\hline & \multicolumn{2}{c}{ Cartel Period } & \multicolumn{2}{c}{ Post-Cartel Period } & \multicolumn{2}{c}{ Overall } \\
\hline List price [€/ton] & 90.98 & $(12.19)$ & 82.76 & $(18.35)$ & 89.40 & $(13.98)$ \\
Net price [€/ton] & 67.89 & $(13.18)$ & 46.00 & $(17.44)$ & 63.68 & $(16.53)$ \\
Absolute Discount [€/ton] & 20.98 & $(12.12)$ & 35.18 & $(18.81)$ & 23.72 & $(14.77)$ \\
Share of Discount & 0.23 & $(0.13)$ & 0.41 & $(0.21)$ & 0.26 & $(0.16)$ \\
Immediate Discount Share & 0.20 & $(0.29)$ & 0.31 & $(0.45)$ & 0.22 & $(0.33)$ \\
Ordered quantity [thousand tons] & 0.23 & $(0.45)$ & 0.26 & $(0.48)$ & 0.24 & $(0.46)$ \\
Overall quantity year [thousand tons] & 79.56 & $(81.83)$ & 63.93 & $(63.17)$ & 76.55 & $(78.82)$ \\
No. firms in 150km & 5.15 & $(1.98)$ & 4.44 & $(1.77)$ & 5.01 & $(1.96)$ \\
Nearest East Euro. plant [km] & 411.60 & $(131.99)$ & 403.02 & $(145.56)$ & 409.95 & $(134.75)$ \\
Direct & 0.19 & $(0.39)$ & 0.52 & $(0.50)$ & 0.25 & $(0.43)$ \\
Consistency 32.5 & 0.31 & $(0.46)$ & 0.30 & $(0.46)$ & 0.30 & $(0.46)$ \\
Consistency 42.5 & 0.66 & $(0.47)$ & 0.65 & $(0.48)$ & 0.66 & $(0.47)$ \\
Consistency 52.5 & 0.03 & $(0.17)$ & 0.05 & $(0.22)$ & 0.03 & $(0.18)$ \\
RMX & 0.0365 & $(0.19)$ & 0.0687 & $(0.25)$ & 0.0427 & $(0.20)$ \\
Unloading region: East & 0.13 & $(0.34)$ & 0.29 & $(0.45)$ & 0.16 & $(0.37)$ \\
Unloading region: West & 0.39 & $(0.49)$ & 0.36 & $(0.48)$ & 0.39 & $(0.49)$ \\
Unloading region: South & 0.45 & $(0.50)$ & 0.34 & $(0.47)$ & 0.43 & $(0.50)$ \\
\hline Observations & 20937 & & 4993 & & 25930 & \\
\hline
\end{tabular}

It is clear from Table 1 that this is a market for which discounts are common. Over the entire period, the average list price is $89.40 €$ per ton while the average net price is $63.68 €$. Thus, buyers pay a price which is more than $25 \%$ below the list price. ${ }^{40}$ Of the discounts given, $22 \%$ were immediate with the remainder occurring as end-of-period rebates. The average quantity shipped is 240 tons per plant-seller-unloading point-month with a large standard deviation of 460 tons. 'Overall quantity year' captures the importance of a customer to a supplier as it measures the quantity of cement that a customer purchased in the current year from all suppliers (aggregating across purchases of all cement types and locations). ${ }^{41}$ The average of this variable in the dataset is 79,560 thousand tons per year. ${ }^{42}$ With respect to the competitive environment around the customers' unloading points, the average number of firms was 5 for the entire period with a slight decrease between the cartel and post-cartel periods from 5.15 to 4.44 . This decline was partly due to the relocation of customers and partly because of plant closures and mergers. More specifically, while some customers are involved in the production of, for example, concrete or paving stones, others

40 This is even more striking when one considers that the price data in Table 1 is not quantity-weighted and one would expect discounts to be increasing with quantity.

41 The rationale for including the contemporary annual purchases of a customer is that annual demand is reasonably foreseeable (e.g., construction projects are planned out well in advance). Furthermore, including the yearly quantity helps identify the effect of quantity on end-of-year discounts (which do not vary in our dataset by construction). As a robustness check, we also used a customer's previous year's purchases from a seller and results are largely unchanged. So as not lose one year of data, we chose to use contemporary annual purchases.

42 As some customers appear more often within one year in the dataset - as they have more unloading points and/or buy from various plants - the reported average has an upward bias. Taking into account every customer only once for each year, the average is 24,411 thousand tons per year with a standard deviation of 36,282 thousand tons per year. 
are pure construction companies. For the latter group of customers, construction sites - and therefore the cement unloading points - change over time.

The binary variable "Direct” indicates whether the invoice came directly from the delivering cement plant (Direct $=1$ ) or whether an intermediary agent arranged the transaction (Direct $=0$ ). In either case, the cement is shipped directly from the plant and thus transportation costs are the same. Interestingly, the respective share of purchases that did not involve an intermediary significantly increased from 18 percent in the cartel period to 52 percent in the post-cartel period. This change supports the allegation made by customers that the cartel members regularly diverted some sales to wholesalers in order to deter them from importing cement. With respect to the type of cement, two-thirds of the observations are for CEM I with strength 42.5, and the remaining are of strength 32.5 and 52.5. The shares of observations for shipments of specific types of CEM I cement do not change substantially over time. Readymix customers make up $4.27 \%$ of the observations in the data set. ${ }^{43}$ Lastly, the data set largely encompasses deliveries to the south, east, and west regions with low coverage of the north region.

\subsection{Econometric Model and Results}

For the purpose of measuring the determinants of price, the following linear model is specified:

$$
y_{c, s, p, t}=\beta_{1}^{\prime} X_{c, s, p, t}+\beta_{2} \text { PostCartel }_{t}+\beta_{3} \text { PostCartel }_{t} * R M X+\varepsilon_{c, s, p, t}
$$

It is estimated for four different price-related dependent variables, $y_{c, s, p, t}$ : list price, net price, discount share, and immediate discount share. Price is specific to the identity of the customer's loading point $c$, the delivering plant $p$, the seller $s$ (which is either an intermediary or the cement plant directly), and time $t$. Vector $X$ includes customer characteristics, a customer's competitive environment, an indicator variable whether a wholesaler was used in the transaction, and properties of the delivered products. PostCartel is an indicator variable that takes the value 1 when the delivery was invoiced after February 2002. RMX indicates that the delivering plant was controlled by Readymix. The interaction of $R M X$ and PostCartel captures how Readymix's prices differed from those of the other cartel members in response to Readymix supplying its subsidiaries in the south. ${ }^{44}$

Cement plants can differ in their cost structures. Furthermore, given the variation in local market structures and transportation costs, it is reasonable to assume that prices are different across

43 Readymix was acquired by Cemex in March 2005. As Cemex was not active in the German market before the acquisition, we chose not to split the $R M X$ variable into two separate variables for Readymix and Cemex. However, the model has been estimated when such a split is done and our main findings are unaffected.

44 Given the use of plant fixed effects, we do not have an indicator variable for $R M X$. 
regions. To account for this unobserved heterogeneity, plant-region-fixed effects are used for the list price estimation. While list prices are the same across customers, net prices and discounts vary across customers and could vary in unobserved ways. Given that customers buy different amounts of cement and operate in different businesses (e.g., construction and concrete production), there can be variation in customer bargaining power. To account for this unobserved heterogeneity, plant-region-customer fixed effects are used in the regressions involving net prices and discounts.

The estimated coefficients are in Table 2. Before focusing on what these estimates tell us about how pricing changed after February 2002, it is useful to examine some of the other determinants of price. While the quantity ordered in a month does not have a significant effect on prices or discounts (which could be due to variation in monthly demand being driven more by seasonal construction activity), customer size as measured by annual purchases has a significant and negative effect on net price, as expected. The bigger the customer, the higher the discount and the bigger the share of the discount that are end-of-year (or, equivalently, the lower its immediate discount share). List prices do not differ with customer size. The number of firms within $150 \mathrm{~km}$ of the unloading point does not have a significant effect during or after Readymix's deviation; any cross-sectional variation may already be picked up by the fixed effects. The distance between the unloading point and the nearest Eastern European plant affects the net price positively, which is consistent with our expectation as prices at Eastern European plants were lower than German prices during the cartel period (thereby partially constraining the market power of the cartel). While "direct invoicing" does not affect list prices, the net prices are significantly lower when the customer did not order the cement through an intermediary. The effect can therefore be thought of as a retail margin which did not change before or after Readymix's deviation. However, as observed in Table 1, the volume of orders that cement suppliers put through the intermediaries was significantly higher under collusion which is consistent with the cartel sharing the collusive rents in order to prevent those intermediaries from importing cement. 
Table 2: Estimation Results for List Prices, Net Prices, and Discounts

\begin{tabular}{|c|c|c|c|c|}
\hline & List price & Net price & Disc. Share & $\begin{array}{c}\text { Imm. Disc } \\
\text { Share }\end{array}$ \\
\hline Ordered quantity & $\begin{array}{l}-0.954 \\
(-1.03)\end{array}$ & $\begin{array}{l}0.201 \\
(0.61)\end{array}$ & $\begin{array}{l}-0.011 \\
(-1.57)\end{array}$ & $\begin{array}{l}-0.012 \\
(-0.79)\end{array}$ \\
\hline Overall quantity year & $\begin{array}{l}0.022 \\
(1.21)\end{array}$ & $\begin{array}{c}-0.060^{* * *} \\
(-5.21)\end{array}$ & $\begin{array}{c}0.001^{* * *} \\
(7.23)\end{array}$ & $\begin{array}{c}-0.001^{* * *} \\
(-3.74)\end{array}$ \\
\hline No. firms in $150 \mathrm{~km}$ & $\begin{array}{l}-0.023 \\
(-0.13)\end{array}$ & $\begin{array}{l}-0.328 \\
(-1.26)\end{array}$ & $\begin{array}{l}0.000 \\
(0.13)\end{array}$ & $\begin{array}{l}0.003 \\
(0.83)\end{array}$ \\
\hline Nearest East Euro. plant & $\begin{array}{l}0.010 \\
(1.55)\end{array}$ & $\begin{array}{c}0.024^{* * *} \\
(3.49)\end{array}$ & $\begin{array}{c}-0.000^{* * *} \\
(-3.05)\end{array}$ & $\begin{array}{c}-0.000^{*} \\
(-1.70)\end{array}$ \\
\hline Consistency 32.5 & $\begin{array}{c}-6.052^{* * *} \\
(-5.60)\end{array}$ & $\begin{array}{c}-3.517^{* * *} \\
(-4.78)\end{array}$ & $\begin{array}{l}-0.003 \\
(-0.27)\end{array}$ & $\begin{array}{l}-0.012 \\
(-0.73)\end{array}$ \\
\hline Consistency 52.5 & $\begin{array}{c}8.161^{* * *} \\
(5.62)\end{array}$ & $\begin{array}{c}10.766^{* * *} \\
(10.11)\end{array}$ & $\begin{array}{l}-0.029^{*} \\
(-1.85)\end{array}$ & $\begin{array}{l}-0.015 \\
(-0.55)\end{array}$ \\
\hline Direct & $\begin{array}{l}-0.226 \\
(-0.11)\end{array}$ & $\begin{array}{c}-3.093^{* *} \\
(-2.01)\end{array}$ & $\begin{array}{l}0.031^{*} \\
(1.84)\end{array}$ & $\begin{array}{c}0.140^{* * *} \\
(3.95)\end{array}$ \\
\hline Post cartel period (PC) & $\begin{array}{c}-10.056^{* *} \\
(-2.43)\end{array}$ & $\begin{array}{c}-24.128^{* * *} \\
(-5.74)\end{array}$ & $\begin{array}{c}0.178^{* * *} \\
(6.21)\end{array}$ & $\begin{array}{l}0.054 \\
(1.02)\end{array}$ \\
\hline No. firms in $150 \mathrm{~km} * \mathrm{PC}$ & $\begin{array}{l}1.192 \\
(1.37)\end{array}$ & $\begin{array}{l}1.048 \\
(1.37)\end{array}$ & $\begin{array}{l}0.000 \\
(0.02)\end{array}$ & $\begin{array}{l}-0.025^{*} \\
(-1.95)\end{array}$ \\
\hline Direct * PC & $\begin{array}{l}-1.116 \\
(-0.46)\end{array}$ & $\begin{array}{l}-0.705 \\
(-0.31)\end{array}$ & $\begin{array}{l}0.015 \\
(0.52)\end{array}$ & $\begin{array}{l}-0.020 \\
(-0.43)\end{array}$ \\
\hline $\mathrm{RMX} * \mathrm{PC}$ & $\begin{array}{c}-40.398^{* * *} \\
(-20.13)\end{array}$ & $\begin{array}{l}2.255 \\
(0.66)\end{array}$ & $\begin{array}{l}-0.439^{* * *} \\
(-19.83)\end{array}$ & $\begin{array}{c}-0.637^{* * *} \\
(-8.05)\end{array}$ \\
\hline Constant & $\begin{array}{c}87.089^{* * *} \\
(27.72) \\
\end{array}$ & $\begin{array}{c}65.195^{* * *} \\
(27.40)\end{array}$ & $\begin{array}{l}0.236^{* * *} \\
(13.49)\end{array}$ & $\begin{array}{c}0.317^{* * *} \\
(5.28)\end{array}$ \\
\hline Observations & 25930 & 25930 & 25930 & 25930 \\
\hline$R^{2}$ & 0.320 & 0.393 & 0.315 & 0.136 \\
\hline Adjusted $R^{2}$ & 0.320 & 0.392 & 0.315 & 0.136 \\
\hline Rho & 0.806 & 0.750 & 0.770 & 0.819 \\
\hline
\end{tabular}

Turning to the differences in pricing by the cartelists before and after Readymix started supplying cement to its concrete subsidiaries in the south region in February 2002, there are two important findings. First, Readymix's deviation did indeed lead to a collapse of the cartel as 
reflected in a radical change in pricing. Net prices fell by $24.13 €$ per ton for both Readymix and the other firms. As the coefficient on $R M X^{*}$ PostCartel in the net price regression is not different from zero, there was no difference in the price decline between Readymix and its rivals over the post-cartel period. Later regressions will shed more light on this result by examining how prices evolved during the post-cartel period.

The second main finding is that there is a striking difference between how Readymix and how the other cement suppliers priced after the cartel's collapse. Though they all lowered net prices by about the same amount, how they got there was very different. Readymix drastically lowered its list price by $50.45 €$ per ton and, at the same time, limited the discounts it gave; the discount as a share of the list price declined by 26.1 percentage points. Readymix also changed the type of discount as it reduced immediate discounts as a share of the total discount by 58.3 percentage points. In sum, Readymix significantly cut list prices, restricted discounts, and moved away from discounts at the time of purchase. Turning to the other cement suppliers, they cut list prices by $10.06 €$ per ton - which is only $20 \%$ of Readymix's cut - and went with higher discounts; the discount share of the list price rose by 17.8 percentage points. There was a slight decline in the use of immediate discounts but it is not statistically significant. ${ }^{45}$

While the preceding analysis is useful for measuring broad changes in pricing before and after Readymix deviated by supplying cement to its subsidiaries producing concrete in the south region, it does not shed light on exactly how these changes played out. Who changed price first? How did they change price? How did other firms respond? To address those questions, the Post-Cartel dummy variable will be replaced with a series of time dummy variables at the quarterly frequency for list prices and at the annual frequency for net prices. The use of annual as opposed to quarterly for net prices is due to their construction which distributes end-of-year discounts uniformly across the preceding 12 months. This means that a change in the composition of discounts (between immediate and end-of-year) could cause a change in net prices at the quarterly frequency to be an artifact of the construction. That concern is absent with the use of annual frequency.

Beginning with list prices, let us now estimate the following adaptation of our econometric model:

$$
P_{c, s, p, t}^{\text {List }}=\beta_{1}^{\prime} X_{c, s, p, t}+\beta_{2}^{\prime} \text { PostCartelQuarter }_{t}+\beta_{3}^{\prime} \text { PostCartelQuarter }_{t} * R M X+\varepsilon_{c, s, p, t}
$$

45 The list price equation was also estimated with only region fixed effects, only plant fixed effects, and no fixed effects and results generally do not change. In particular, it is still the case that the estimated coefficient on PostCartel*RMX is large, negative, and statistically significant. Similarly, the net price equation was estimated with every permutation of plant, region, and client fixed effects and our main findings are robust. 
Instead of including the PostCartel indicator for the entire post-cartel period, there are quarterly indicator variables starting with the Nov 2001 - Jan 2002 quarter. The same specification applies for the interaction with the $R M X$ indicator variable. Table 3 presents the results.

Table 3: Estimation Results for List Prices with Quarterly Post-Cartel Indicators

\begin{tabular}{|c|c|c|c|c|c|}
\hline Variable & Coefficient & t-statistic & Variable & Coefficient & t-statistic \\
\hline Ordered quantity & -0.989 & $(-1.03)$ & Consistency 32.5 & $-6.113^{* * *}$ & $(-5.94)$ \\
\hline Overall quantity year & 0.021 & $(1.12)$ & Consistency 52.5 & $8.388^{* * *}$ & (5.98) \\
\hline No. firms in $150 \mathrm{~km}$ & -0.016 & $(-0.09)$ & Direct & -0.386 & $(-0.18)$ \\
\hline $\begin{array}{l}\text { No. firms in } 150 \mathrm{~km} * \\
\text { PC }\end{array}$ & 0.542 & $(0.77)$ & Direct * PC & 1.552 & $(0.75)$ \\
\hline Nearest East Euro. plant & 0.009 & $(1.62)$ & Constant & $87.561^{* * *}$ & $(28.92)$ \\
\hline PC. Q0 & $1.043^{* *}$ & $(2.25)$ & PC.Q0*RMX & $-33.484^{* * *}$ & $(-33.02)$ \\
\hline PC. Q1 & -1.705 & $(-0.59)$ & PC.Q1*RMX & $-36.921^{* * *}$ & $(-18.42)$ \\
\hline PC. Q2 & -2.198 & $(-0.58)$ & PC.Q2*RMX & $-48.984^{* * *}$ & $(-14.05)$ \\
\hline PC. Q3 & -2.961 & $(-0.80)$ & PC.Q3*RMX & $-53.306^{* * *}$ & $(-14.14)$ \\
\hline PC. Q4 & -4.829 & $(-1.24)$ & PC.Q4*RMX & $-46.103^{* * *}$ & $(-6.72)$ \\
\hline PC. Q5 & -7.094 & $(-1.63)$ & PC.Q5*RMX & $-40.920^{* * *}$ & $(-6.69)$ \\
\hline PC. Q6 & -5.74 & $(-1.50)$ & PC.Q6*RMX & $-43.812^{* * *}$ & $(-11.17)$ \\
\hline PC. Q7 & -6.408 & $(-1.63)$ & PC.Q7*RMX & $-44.652^{* * *}$ & $(-12.99)$ \\
\hline PC. Q8 & -5.547 & $(-1.46)$ & PC.Q8*RMX & $-50.789^{* * *}$ & $(-19.11)$ \\
\hline PC. Q9 & $-7.891^{* *}$ & $(-2.12)$ & PC.Q9*RMX & $-54.015^{* * *}$ & $(-12.90)$ \\
\hline PC. Q10 & $-14.454^{* * *}$ & $(-3.82)$ & PC.Q10*RMX & $-42.968^{* * *}$ & $(-16.69)$ \\
\hline PC. Q11 & $-14.654^{* * *}$ & $(-3.88)$ & PC.Q11*RMX & $-43.611^{* * *}$ & $(-16.66)$ \\
\hline PC. Q12 & $-17.267^{* * *}$ & $(-4.53)$ & PC.Q12*RMX & $-40.778^{* * *}$ & $(-15.47)$ \\
\hline PC. Q13 & $-17.293^{* * *}$ & $(-5.12)$ & PC.Q13*RMX & $-37.185^{* * *}$ & $(-11.88)$ \\
\hline PC. Q14 & $-18.735^{* * *}$ & $(-5.93)$ & PC.Q14*RMX & $-33.169^{* * *}$ & $(-8.14)$ \\
\hline PC. Q15 & $-18.757^{* * *}$ & $(-5.64)$ & PC.Q15*RMX & $-35.142^{* * *}$ & $(-11.37)$ \\
\hline PC. Q16 & $-17.875^{* * *}$ & $(-5.56)$ & PC.Q16*RMX & $-38.316^{* * *}$ & $(-14.92)$ \\
\hline Observations & 25930 & & Adjusted $R^{2}$ & 0.404 & \\
\hline$R^{2}$ & 0.405 & & Rho & 0.823 & \\
\hline
\end{tabular}

$t$ statistics in parentheses; Price was deflated; Standard Errors are robust to heteroscedasticity; Regression includes plant-region fixed effects; ${ }^{*} p<0.1,{ }^{* *} p<0.05,{ }^{* * *} p<0.01$

Recall that Readymix announced in November 2001 that it would start supplying cement to its concrete subsidiaries in the south region and subsequently implemented this change starting in February 2002. Table 2 shows that Readymix drastically lowered its list prices by 32.44€ per ton in the quarter between the announcement and implementation, and continued to lower list price for 
several quarters thereafter. In contrast, the list prices of the other cartelists did not change in the immediate aftermath of either Readymix's announcement or implementation. The movement in list prices supports the hypothesis that, in response to Readymix’s November 2001 announcement, the other firms did not retaliate, while Readymix complemented its deviation in the south with a much broader deviation by lowering list prices. It took 9 quarters for the other firms to start lowering their list prices though, as we'll see in the next regression, net prices responded sooner.

It is worth emphasizing that Readymix chose to deviate from the collusive arrangement by lowering its list prices rather than secretly offering discounts and maintaining its publicly observed list prices. This strategy is consistent with Readymix believing that its announcement would mean the collapse of the cartel in which case it would be optimal to focus on maximizing current profit. In the short-run, lowering list price would have a bigger impact on demand than increasing discounts because all prospective buyers would learn about a lower list price while only those which negotiated with Readymix would learn about higher discounts. It appears that Readymix attached little hope to collusion being sustained and was intent on increasing demand.

Consistent with its strategy to attract customers from other cement suppliers, Readymix's reduction in its list price was so great that its list price was significantly below the net price during the cartel phase. To make that comparison, let us focus on directly invoiced consistency 42.5 cement. Using the estimated equation for net price from Table 2, the fitted net price during the cartel period is $65.56 €$ per ton (assuming the other variables are set at their averages during the cartel period). Let us compare this net price with the list prices right after Readymix's deviation, based on the estimated coefficients from Table 3. The fitted list price is 59.67€ for the Nov 2001 Jan 2002 quarter and 57.37€ for the Feb 2002 - May 2002 quarter (assuming the other variables are set at their averages for the respective quarter). Thus, even before applying discounts - which Readymix still offered after its deviation (though to a far lesser extent) - a customer would have observed that Readymix's list price was below the net price it was paying to the other cartelists. This is compelling evidence that Readymix was aggressively going after market share by posting a price that would attract customers.

Even after the initial deviation from the cartel, there was a persistent difference in the pricing strategies of Readymix and the other cement suppliers as reflected in the quarterly time dummies. While the latter firms eventually reduced their list prices, Readymix consistently had lower list prices throughout the entire post-cartel period. Indeed, it was not until early 2004 that there is statistical support for the other firms' list prices being below their levels during the cartel period. 
In contrast, Readymix's list price was immediately and significantly below net prices during the cartel phase and also below other firms’ list prices throughout the post-cartel period.

This difference in pricing strategies is consistent with Readymix being discontent with its market share and thereby giving more weight than other firms to growing its sales. A low list price is more effective at attracting new customers to Readymix, while high discounts (and a low net price) is more effective at retaining existing customers (especially in response to them having competitive offers from other suppliers). ${ }^{46}$ However, before drawing any conclusions, it is essential that we examine what was happening with net prices, which we turn to next.

The following equation was estimated for net prices which has annual dummy variables during the post-cartel period:

$$
P_{c, s, p, t}^{N e t}=\beta_{1}^{\prime} X_{c, s, p, t}+\beta_{2}^{\prime} \text { PostCartelYear }_{t}+\beta_{3}^{\prime} \text { PostCartelYear }_{t} * R M X+\varepsilon_{c, s, p, t}
$$

The estimates are in Table 4.

Table 4: Estimation Results for Net Prices with Annual Post-Cartel Indicators

\begin{tabular}{lcclcc}
\hline Variable & Coefficient & S.D. & Variable & Coefficient & S.D. \\
\hline Ordered quantity & -0.071 & $(-0.17)$ & PC: Year 2002 & $-8.740^{* * *}$ & $(-3.75)$ \\
Overall quantity year & $-0.053^{* * *}$ & $(-3.68)$ & PC: Year 2003 & $-28.712^{* * *}$ & $(-9.95)$ \\
No. firms in 150km & $-0.376^{*}$ & $(-1.68)$ & PC: Year 2004 & $-21.293^{* * *}$ & $(-11.42)$ \\
No. firms in 150km * PC & -0.297 & $(-1.00)$ & PC: Year 2005 & $-21.688^{* * *}$ & $(-7.07)$ \\
Nearest East Euro. plant & $0.030^{* * *}$ & $(4.60)$ & PC * RMX: Year 2002 & $-10.716^{* *}$ & $(-2.41)$ \\
Consistency 32.5 & $-3.322^{* * *}$ & $(-4.73)$ & PC * RMX: Year 2003 & $19.618^{* * *}$ & $(3.58)$ \\
Consistency 52.5 & $10.637^{* * *}$ & $(9.35)$ & PC * RMX: Year 2004 & $5.209^{* *}$ & $(2.23)$ \\
Direct & -2.308 & $(-1.48)$ & PC * RMX: Year 2005 & 2.651 & $(0.76)$ \\
Direct * PC & 2.103 & $(0.99)$ & Constant & $62.435^{* * *}$ & $(22.42)$ \\
\hline Observations & 25930 & & Adjusted $R^{2}$ & 0.476 & \\
$R^{2}$ & 0.477 & & Rho & 0.782 & \\
\hline
\end{tabular}

$t$ statistics in parentheses; net prices are deflated; Standard Errors are robust to heteroscedasticity; Regression includes plant-region-customer fixed effects; ${ }^{*} p<0.1,{ }^{* *} p<0.05,{ }^{* * *} p<0.01$

In the first year after its deviation, Readymix decreased its net price by $19.46 €$ per ton while the other cement suppliers lowered their net prices by $8.74 €$ per ton. While Readymix had then reduced its net price $10.74 €$ per ton more than its rivals in 2002, this pattern reversed in 2003 as, compared to the cartel period, Readymix’s net price was 9.09€ per ton lower but the other cement suppliers' net prices were $28.71 €$ per ton lower; Readymix had then increased its net price by $19.62 €$ per ton more than the other firms. This gap reduced to $16.08 €$ per ton in 2004 and disappeared by 2005 so that net prices were comparable between Readymix and the other major cement suppliers.

46 As we only have a relatively small sample of customers in the market, we do not have the market share data to determine whether Readymix succeeded in growing its market share. 
One interpretation of this pattern is that Readymix initially sought to grow its market share by drastically lowering its list price and undercutting the net prices of the other cement suppliers. If that strategy proved unprofitable, it would explain why Readymix reversed course and raised net prices in 2003. However, at the same time, the other suppliers were responding aggressively by further cutting their net prices. This competition settled down by the last year of the sample as there was no noticeable difference in the net prices of Readymix and its rivals though net prices were $21.69 €$ per ton lower than during the cartel period.

Let us conclude by summarizing our assessment of the collapse of the German cement cartel. In response to its capacity expansion and declining market demand, Readymix decided to deviate from the collusive allocation by supplying cement to its concrete subsidiaries that were currently supplied by other cartel members and drastically cutting prices. However, Readymix did not deviate by secretly raising discounts but instead drastically cut publicly observed list prices to levels below that of net prices under collusion. Such a strategy was likely to have been more effective at attracting new customers and thereby growing sales. However, at the same time, it was likely to bring retaliation by other firms which it did as Readymix's rivals increased their discounts and cut net prices. While Readymix had lower list and net prices than other cement suppliers in the year after the cartel's collapse, which is consistent with them trying to grow market share, the subsequent aggressive retaliation by Readymix's rivals brought their net prices below that of Readymix's. Eventually, the net prices of Readymix and the other large cement suppliers were comparable though that took several years to achieve.

\section{Concluding Remarks}

Cartels, like any institution, do not last forever. While the demise of a cartel is an inevitable event, when and why collapse occurs is not well-understood. Using facts from past cartels, we hypothesized that some cartels may have the seeds of their own destruction. An often contentious element to collusion is settling upon a market allocation. A common resolution to this dilemma is to use historical market shares. While that may have a certain fairness attached to it, it can result in cartel members initially or eventually becoming discontent as this freezing of the relative positions of firms can run counter to growth aspirations. This situation can become particularly acute when a firm expands capacity but growth in market demand is insufficient to adequately utilize that new capacity. When that arises, the temptation to cheat on the collusive allocation is accentuated and this can result in the collapse of the cartel.

This hypothesis has been argued to fit the experience of the German cement cartel of 1991- 
2002. Cartel member Readymix made a major capacity expansion in the early 1990s based on forecasts of demand growth in post-unification eastern Germany. When demand stopped growing and actually contracted, Readymix produced above its quota and unsuccessfully sought to hide its deviation from the other cartel members. Eventually, Readymix chose a more egregious and conspicuous cheating strategy that resulted in the collapse of the cartel.

The cartel instability documented here highlights a systematic phenomenon in which some a firm conspicuously cheats on the collusive allocation in spite of running the risk of cartel collapse. While the rich and varied theory of collusion is able to explain many aspects of collusive practices and outcomes, it does not yet have a theory that can produce this form of cartel instability. The development of such a theory is needed if we are able to better understand not just the market conditions that promote cartel birth but also the market conditions that cause cartel death. 


\section{References}

Blum, Ulrich, The East German Cement Cartel: Cartel Efficiency and Cartel Policy after Economic Transformation, Eastern European Economics, 45 (2007), 5-28.

Friederiszick, Hans W. and Lars-Hendrik Röller, Lokale Märkte unter Gobalisierungsdruck. Eine industrieökonomische Studie zur deutschen Zementindustrie, (on behalf of the German Ministry of Economics and Labour), RACR Studie 01, 2002.

Friederiszick, Hans W. and Lars-Hendrik Röller, “Quantification of Harm in Damages Actions for Antitrust Infringements: Insights from German Cartel Cases,” Journal of Competition Law and Economics, 6 (2010), 595-618.

Genesove, David and Wallace P. Mullin, "Rules, Communication, and Collusion: Narrative Evidence from the Sugar Institute Case,” American Economic Review, 91 (2001), 379-398.

Harrington, Joseph E. Jr., "How Do Cartels Operate?," Foundations and Trends in Microeconomics, 2 (2006).

Harder, Joachim, “End of the Crisis in the German Cement Industry,” Onestone Consulting Group Report, Buxtehude, 2006.

Hortaçsu, Ali and Chad Syverson, "Cementing Relationships: Vertical Integration, Foreclosure, Productivity, and Prices,” Journal of Political Economy, 115 (2007), 250-301.

Hüschelrath, Kai and Tobias Veith, “Cartel Detection in Procurement Markets,” Managerial and Decision Economics, 35 (2014), 404-422.

Hüschelrath, Kai and Tobias Veith, “The Impact of Cartelization on Pricing Dynamics,” ZEW Discussion Paper No. 11-067, Mannheim, 2011.

Levenstein, Margaret C., "Price Wars and the Stability of Collusion: A Study of the Pre-World War I Bromine Industry,” Journal of Industrial Economics, 45 (1997), 117-137.

Levenstein, Margaret C., "Do Price Wars Facilitate Collusion? A Study of the Bromine Cartel before World War I,” Explorations in Economic History, 33 (1996), 107-137.

Levenstein, Margaret C. and Valerie Y. Suslow, "What Determines Cartel Success?,” Journal of Economic Literature, 44 (2006), 43-95.

Levenstein, Margaret C. and Valerie Y. Suslow (2011), “Breaking Up Is Hard To Do: Determinants of Cartel Duration,” Journal of Law and Economics, 54 (2011), 455-492.

Miller, Nathan H. and Matthew Osborne, "Spatial Differentiation and Price Discrimination in the Cement Industry: Evidence from a Structural Model,” RAND Journal of Economics, 45 (2014), 221-247. 